\title{
Immigrant Narratives: \\ Power, Difference, and Representation in Young-Adult Novels with Immigrant Protagonists
}

\author{
Elizabeth Clifford \\ Towson University
}

U. S. A.

Maya Kalyanpur

Ministry of Education, Youth and Sports

Cambodia

As of 2008 , about $23 \%$ of children in the United States were immigrants or the children of immigrants. This paper examines how immigrants are portrayed in books aimed at teenagers. From a sample of 20 young-adult novels we look at the demographics of both protagonist and author and examine how three main themes are addressed: 1) experiences prior to immigration, 2) journeys of immigration, and 3) adjustments due to immigration. Finally, we explore how the issues of power, difference, and representation play out in these immigrant narratives.

\author{
Introduction \\ Methodology \\ Results \\ Discussion \\ Conclusion \\ Notes \\ References \\ Appendix
}

\section{Introduction}

As of 2008 , about $23 \%$ of children in the United States were immigrants ${ }^{1}$ or the children of immigrants (Fortuny, 2010). Within the context of multicultural education, it is therefore important for educators and scholars to consider what messages are available about immigrants and immigration. Hinton (2006) argues that it has become widely recognized that multicultural literature is a key component of multicultural education. She embraces Bishop's definition of multicultural literature as reflecting "the racial, ethnic, and social diversity that is characteristic of our pluralistic society and the world" (cited in Hinton, 2006, p. 51). Immigrant narratives clearly fit Bishop's definition and speak to Loh's (2009) call for multicultural literature that extends beyond the boundaries of the United States.

Media scholars are paying more attention to messages about immigrants 
targeted towards children, such as Mullen's (2004) research on how immigrants are portrayed in children's literature and folksongs; Lamme, Fu, and McKoy's (2004) work on immigrants in children's picture books; and Keis' (2006) article on the use of children's literature in a rural Latino community. We join these scholars in wanting to understand the immigrant portrayals young people are absorbing from books.

We chose to focus on young adult fiction with immigrant protagonists, specifically selecting this genre because identity formation is a crucial part of adolescent life (Erikson, 1980). We argue that young adult fiction with immigrant protagonists can serve an important role in reaching immigrant youth, who may appreciate reading about characters portrayed as having gone through similar experiences as they have. We believe that such fiction can also serve to educate native-born youth about what their immigrant peers' lives are like. This literature can only have such positive effects, however, if the portrayals of immigrants are complex and multifaceted, while simplistic or negative images could lead to more friction between immigrants and the native-born. We concur with Mullen (2004), who argues that "understanding the factors that affect the portrayal of ethnic immigrants could help to understand children's intergroup perceptions" (p. 251). In addition, we agree with Loh (2009), who makes the case that "literary narratives are a rich resource for conversations about issues that preoccupy self and world" (p. 294).

\section{Methodology}

We conducted a content analysis of 20 young adult novels published since 2000 , focusing on realistic fiction. The books are listed in Table 1 (see details on each book in the Appendix). The sample was garnered using searches on Amazon.com. We searched young adult fiction, using the terms "immigrant" and "immigration." We ordered the list based on popularity and sorted out those that had immigrant protagonists. We wanted to focus on books that had been widely read and so chose the first 20 (those that had sold the most copies). Although we did not draw our books from lists of award winners, after choosing our sample we discovered that 10 of the 20 had indeed won awards, and an additional seven were written by award-winning authors (analyzed using Bartle, 2008).

Table 1. Books Selected for Analysis

\begin{tabular}{|l|}
\hline Mary Jane Auch (2002). Ashes of Roses \\
\hline Anjali Banerjee (2005). Maya Running \\
\hline Jackie Brown (2004). Little Cricket \\
\hline Marina Budhos (2006). Ask Me No Questions \\
\hline Edwidge Danticat (2002). Behind the Mountains \\
\hline
\end{tabular}




\begin{tabular}{|l|}
\hline Melissa De La Cruz (2005). Fresh off the Boat \\
\hline Helen Frost (2006). The Braid \\
\hline Will Hobbs (2006). Crossing the Wire \\
\hline Kathryn Lasky (2005). Broken Song \\
\hline Alice Mead (2005). Swimming to America \\
\hline An Na (2001). A Step From Heaven \\
\hline Donna Jo Napoli (2005). The King of Mulberry Street \\
\hline Mitali Perkins (2005). The Not-So-Star-Spangled Life of Sunita Sen \\
\hline Kashmira Sheth (2004). Blue Jasmine \\
\hline John Son (2003). Finding My Hat \\
\hline Eve Tal (2005). Double Crossing \\
\hline Ana Veciana-Suarez (2002). Flight to Freedom \\
\hline Rita Williams-Garcia (2004). No Laughter Here \\
\hline Paul Yee (2004). The Bone Collector's Son \\
\hline Benjamin Zephaniah (2001). Refugee Boy \\
\hline
\end{tabular}

Drawing from our knowledge of the immigration process, we knew prior to reading the books that there were three key topics we wanted to examine in these portrayals: experiences prior to emigration/immigration ${ }^{2}$, the journey of immigration, and adjustments due to immigration. We wanted to see what issues arose in regards to these key moments in the immigration process. Thus, we put together a rubric ${ }^{3}$ covering these three areas to use in analyzing the novels. We also used the rubric to note key elements about plot and characterization. Lastly, we kept notes on pertinent demographic details about both protagonists and authors, including cases in which the authors were writing from their own or familial immigrant experience. Each of us read and analyzed about half of the novels.

We began to focus on the demographics of authors when we noticed the strong autobiographical, albeit fictionalized, aspects of both characterization and story line. For instance, eight of the 20 authors were themselves immigrants (from Haiti, the Philippines, Cuba, Korea, and India), and these authors often relied on their personal experiences in writing their novels. All eight created protagonists of their own nationality. In some cases the similarities went even further. Three Indian authors, for example, created protagonists who were from their region or state and sub-caste. One author gave the protagonist her maiden name, and another named a main character after her immigrant grandmother. Seven other authors stated, in authors' notes at the end of the book, that the stories were based on the experiences of a close family member, most often a 
grandparent. Kathryn Lasky (2005) dedicates her Broken Song, a story that begins in the Russian Pale, to her grandparents "who endured these times." The implications of these thinly veiled autobiographical characterizations are analyzed later in the section on representation.

We chose not to narrow our analysis to books solely about one particular group of immigrants. We were interested to see what groups were being written about, and we wanted to capture a wide variety of experiences. We did indeed garner a diverse group of protagonists: in the 20 books, the protagonists represented 15 nationalities, including countries in Asia, Europe, Latin America, the Caribbean, and Africa. Interestingly, both the authors and protagonists were overwhelmingly female (18 out of 20 authors and 15 out of 21 protagonists ${ }^{4}$ ).

Most of the protagonists were in their early to mid-teenage years, although a few stories began earlier in the protagonists' lives, sometimes when they were toddlers. Many protagonists had experiences and responsibilities that were much more adult than most American children would now experience. This was particularly true of the historical novels. For example, in the historical novel The King of Mulberry Street, it is easy to forget that the protagonist, Dom, is only nine years old, as he fends for himself on the streets of New York and begins a vending business employing other immigrant boys (sometimes older than himself) (Napoli, 2005).

The protagonists also represented a variety of religions, including Christianity, Hinduism, Judaism, Buddhism, Islam, and Animism. The novels varied greatly as well in terms on how central religion was in the protagonists' lives. In some cases, religion was a key facet in the lives of the young people and their families. For instance, in Double Crossing (Tal, 2005), the book revolves around the protagonist's father having to decide to give up "being a Jew" as he understood and practiced Judaism in order to "become an American." In other stories, religion was more tangential, and in still others religion was not mentioned.

The books varied also in terms of the eras covered. Six took place between the mid-1800s and early 1900s (we refer to these as the "historical" books); four took place in the period from the late 1960s through the 1980s, after immigration reforms of the 1960s increased and diversified the number and origins of immigrants entering the country (Portes \& Rumbaut, 2006); and the remaining nine were more recent (1990s and 2000s). The exact time period of one book was unclear.

The protagonists settled in many areas of the United States, Canada, and the United Kingdom. Chief among the areas of settlement were New York City and California, reflecting actual historical and current settlement patterns.

\section{Results}

In analyzing these stories, we recognize that they are just that - stories or 
fictional accounts. We are interested, in this paper, in how immigrants and the experience of immigration are portrayed, rather than what the experience actually is. These portrayals may shape how young people understand immigration, and thus they are important to understand.

In our analysis, we examined the authors' descriptions of three major events of the protagonists' experiences in the process of immigration: experiences prior to emigration/immigration, journeys of immigration, and adjustments due to immigration. For experiences prior to immigration, we analyzed the narrative that takes place in the home country and the circumstances that lead to emigration. In some cases, none of the story takes place in the home country, but the protagonist or other characters recollect memories of the home country. For journeys of immigration, we analyzed transportation methods, difficulties along the journey, and persons accompanying the protagonist. In examining the adjustment process, we analyzed concerns about language, religion, food, and other aspects of culture. In some cases, status dislocation, education levels, and immigration status made adjustment more difficult.

\section{Experiences Prior to Emigration/Immigration:}

Lamme, Fu, and Lowery's (2004) analysis found that children's picture books tended to brush over negative or difficult information, presenting an unrealistically rosy picture of immigrants' lives. This was not the case in these books for young adults. To the contrary, they often offered bleak and dismal pictures of the immigrant experience. The authors created stories of experiences prior to immigration which included poverty, discrimination, and violence. For many of the immigrant characters, these experiences contrasted with unrealistically optimistic notions about America. Yet, when faced with the realities of immigration, many looked back fondly on at least some aspects of their lives in their home countries. This issue of straddling two worlds is a major sub-text within the third theme of adjustment and will be discussed in more detail later.

Poverty is a key focus in many of the books, particularly the historical stories. In The Braid, author Helen Frost (2006) portrays Jeannie, who faces starvation in her native Scotland in the 1850s. Frost explains that Scots were banned from fishing for mussels-a staple of their diet-because the English landlords wanted to use the mussels for bait. John Son's Finding My Hat (2003) describes the poverty that impelled the protagonist's father to emigrate from Korea, first to Germany and then to the United States. He notes that everybody was poor in Korea, they did not have enough to eat, and their health was bad.

Violence was another common thread in the immigrant stories. The authors created stories in which protagonists or their parents had faced violence, often connected with war, in Laos, Bangladesh, Haiti, Albania, Russia, Ethiopia, Eritrea, El Salvador, and Cambodia. In Broken Song, Lasky (2005) creates a 
story about Reuven who witnessed the Tsar's soldiers kill most of his family and village in the late 1890s Russian Pale. Jackie Brown (2004) writes of Kia, in Little Cricket, seeing Communist soldiers come into her Laotian village and attack the Hmong living there: "Just before dawn the Communists amused themselves by shooting at the legs and feet of the women, pretending to make them dance. The young soldiers laughed and yelled, 'Look at the meos ${ }^{5}$ dance! They are not lazy now!'” (p. 32). Sometimes the protagonists themselves had been hurt. Danticat (2002), who loosely based Behind the Mountains on her own immigrant experience, writes a story about Celiane. This protagonist is injured while riding in a bus from Port-au-Prince to her home village in Haiti, when an explosion hits the bus during election violence.

However, not all of the recollections the authors created are negative. Indeed, even those fleeing violence, war, and poverty had fond memories of their pre-immigration lives. Often protagonists miss extended family members and the once-familiar cultural milieu of their homelands. For example, Little Cricket (Brown, 2004) begins with Kia reminiscing fondly about her life in Laos. "In her mind Kia heard the soft snuffle of pigs and the self-important cluck of chickens pecking in the dirt around the bamboo hut. And, best of all, she was no longer alone. The sparkling laughter of her cousins rang in the clear mountain air as they helped the women drop rice seeds in the holes" (p. 2). In Napoli's The King of Mulberry Street (2005), Beniamino and his mother are stigmatized both as a single-parent family and as Jews in Italy, but they are surrounded by a loving extended family, as they live with a number of uncles, aunts, cousins, and his grandmother.

In cases where authors wrote of some family members emigrating before the rest of the family, difficulties of separation and communication ensue. In Behind the Mountains, Danticat's story (2002) tells of Celiane's father, who emigrates earlier while she, her brother, and mother stay behind with her grandparents and other relatives in Haiti. The author, whose parents initially left her in Haiti when they emigrated, describes how Celiane's father communicates by sending tape cassettes home. It is difficult for Celiane to talk on a cassette to send back or to write a letter. She worries, "Maybe I don't know my father anymore. Maybe he has changed ... I am even more worried now that I will not know what to say to Papa when I see him again" (p. 16). She also worries that he might have another family in the United States. ${ }^{6}$ Seema, in Blue Jasmine (Sheth, 2004), has a particularly rich description of the switch from a large extended family to a small nuclear family that is often a part of the immigration process. "From that day on, the four of us, Pappa, Mummy, Mela and I broke off from our family the way ice breaks off from a whole snow cone. In some ways, the lump is still the same as it was on the snow cone, but somehow, after it breaks off, it's different. It melts away too fast and it doesn't taste as good as the whole snow cone does" (p. 3).

One last aspect of the protagonists' experiences prior to immigration is the ideas they have of America prior to immigrating. The most extravagant ideas come from the protagonist of Double Crossing (Tal, 2005). Her "knowledge" of 
America comes from letters other Russian Jews who had already immigrated sent home: "By the time I was eleven in 1905, I knew all the stories about becoming rich in America...no one has to work, gold and silver coins grow on trees, and every day, in America, they eat roast chicken for dinner, and for dessert, they eat honey cake and poppy cake and oranges" (p. 12). They are aware that escaping Russia also means escaping the pogroms, and they think that there will not be any anti-Semitism in America. Towards the end of the book, when Rachel asks unbelievingly, "Do you think there is anti-Semitism even in America?" she is told, "I never heard of a Jew being killed in a pogrom in America, but in the South they hang black men from trees" (p. 240). Thus, in the same narrative, there is both an extremely unrealistic picture of the economic situation in America, as well as a dose of the reality of American race relations.

\section{Journeys of Immigration}

Although the historical and more recent accounts differed on means of transportation used to immigrate, there were several commonalities across the books. A number of the accounts involved elements of escape, often with quite treacherous journeys. In others, encounters with immigration officials loom large, especially when the protagonists and their families are trying to enter the country under false pretenses.

The historical accounts all involved boat travel. Authors wrote of immigrants traveling by steerage class on boats (normally reserved for cattle or steers) and give descriptions of the hardships steerage entailed. In The Bone Collector's Son (Yee, 2004), Bing is horribly seasick as he travels steerage from China to the United States in 1907. In Double Crossing (Tal, 2005), the 50 steerage passengers have to fight for space in a large windowless room, sleep on three-tier bunk beds, and share six toilets. Not surprisingly, in these conditions many passengers become seasick, and the room reeks of vomit. There are also difficulties getting food to eat, heightened by the fact that the limited amount of food available to them is not kosher, and thus is inedible to this Jewish family. In The Braid (Frost, 2006), three members of Jeanie's family, including her father, die of cholera, due at least in part to the conditions faced in steerage. Again, these are all fictional accounts but mirror actual accounts of the conditions of travel in the past.

Most modern accounts featured air travel. Some protagonists see the plane trips as symbolic. In A Step from Heaven ( $\mathrm{Na}, 2001)$, being up in the clouds in the plane deepens the protagonist's conviction that "Mi Gook" (meaning America with a literal translation of a beautiful country) must be heaven, while in Blue Jasmine (Sheth, 2004) and Flight to Freedom (Veciana-Suarez, 2002) the authors use the plane trip to America from Bombay and Cuba respectively as a metaphor for their protagonists' suspension between two worlds. As Yara's father describes in the latter book, "We belonged nowhere, not in Cuba and not in the United States. Maybe exile means staying forever in an airplane, suspended over 
an ocean between two countries, just like we are now" (Veciana-Suarez, 2002, p. $34)$.

Some contemporary accounts also involve travel via boat, foot, or mule. For example, in Behind the Mountains (Danticat, 2002), Celiane's Haitian mountain village home is quite remote, and so they must first walk, then ride a mule to the nearest town, from which they are driven in a car to the Port-auPrince airport.

In some of the historical and modern novels, the protagonists and their families flee their home countries in wartime conditions. The authors who write about these journeys create harrowing accounts. In Little Cricket (Brown, 2004), Kia and her family escape on foot from Laos to Thailand, forced at one point to eat rats for sustenance, as "the bombs dropped around them, sometimes so close the ground shook" (p. 65). In Broken Song (Lasky, 2005), 15-year-old Reuven travels across Russia and Poland during the winter carrying his infant sister, the only other surviving member of his family, on his back. Raizel also flees Russian pogroms in Double Crossing (Tal, 2005).

In Swimming to America (Mead, 2005), eighth-grader Linda was too young at the time of immigration to have clear memories of her journey from Albania, but she suffers from unexplained nightmares and flashbacks. Eventually, her mother shares with her that the journey involved flying from Greece to Mexico with forged documents, and then traveling from there to the United States. "The plan was that the Mexicans on that side of the border would drop us off at the river. On the other side of the river is America...they told us the Rio Grande is very shallow..." (p. 111). However, the river ends up being deeper than expected, with a strong current and searchlights trained on it. Her mother tells her, "We had to duck our heads down in the water when [the searchlight] came past. But you didn't understand. I had to put your head under. You kicked me and fought. So I had to pinch your nose and duck you under. And then you would try to scream and your mouth would fill up with water" (pp. 111-112). Later, they are smuggled in the trunk of a car for six hours, where Linda's mother keeps Linda from being heard by stuffing a sock in her mouth. "I cried to myself in silence because I was afraid you might suffocate" (p. 113). This account explains Linda's recurrent nightmares, in addition to helping her understand the extraordinary circumstances of her parents' journey to the United States.

Less physically difficult, but equally anxiety-ridden, are the encounters with immigration officials at the protagonists' countries of destination. Some, like Linda's family in Swimming to America (Mead, 2005), avoid contact with immigration officials by entering illegally (and treacherously). Others, however, cannot avoid this encounter. In some of the historical descriptions, the immigrants encountered officials at Ellis Island, or its Canadian counterpart. Both Double Crossing (Tal, 2005) and Ashes of Roses (Auch, 2002) describe the ordeal of a physical inspection at Ellis Island: how the eyes were examined for disease using a metal hook to pinch the eyelids and hold the eye open. In both books, family members were turned away: in one because of an eye disease, and in the other because of the possibility that the educated but unskilled father 
could become a state liability.

The contemporary accounts also involve stressful encounters with immigration officials at airports, rather than at Ellis Island. Trying to enter under false pretenses increases the families' stress. In Fresh off the Boat (DeLaCruz, 2005), Vicenza's family is trying to enter on tourist visas but plans to stay and petition for green cards. To convince the officials that they are, indeed, tourists, they dress in their best clothes. "My mother wore her tan Burberry raincoat and her Christian Dior sunglasses. She was wearing her most expensive dress, her most impressive shoes. She thought it best to disguise the fact that we were leaving our country forever, flying the coop, never going back. Who in their right mind would immigrate in designer heels? We were playing the part of rich tourists" (p. 59). Vicenza worries that the valuables hidden in their luggage will give them away if customs officials decide to search them.

Refugee Boy (Zephaniah, 2001) describes a similar attempt to appear as tourists. In this case, however, Alem, the protagonist, believes that they are, indeed, tourists, merely traveling to London from Ethiopia for a birthday treat. He is unaware that his father plans to leave him in England, away from the border skirmish that makes life dangerous for Alem's Ethiopian-Eritrean family. The customs official believes that they fit the profile of asylum seekers and questions them extensively. Similarly, in Ask Me No Questions (Budhos, 2006), an account of undocumented Muslim immigrants fleeing post-9/11persecution, Nadira's family attempts to flee to Canada from the United States. When the Canadian immigration officials turn them away, U.S. officials claim that her father is undocumented and he is detained. Nadira later saves the day when she discovers that his detention is a case of mistaken identity.

\section{Adjustments Due to Immigration}

The third defining event in the process of immigration, adjusting to the new country, is a primary theme in the narratives and is the most closely linked to the issue of self-identity. More important, adjustment is not a one-time event but an on-going, perhaps lifelong process. Although the physical journey may be over, the emotional journey has just begun and the authors' depictions of the protagonists' struggles to adjust illustrate the dilemmas of straddling two worlds and the feeling of not belonging in either. Several authors create narratives in which they describe their protagonists' adjustment and those of other characters, mostly family members, as a literary device to demonstrate differences in acculturation. For some characters, the assimilation is easily accomplished, but for most simple everyday acts like choosing what to eat or wear serve as constant reminders of the sense of difference and the perceived need to give up a part of oneself in the effort to belong.

First impressions often create a sense of wonderment and reinforce preimmigrant stories of America as the land of plenty. In Blue Jasmine (Sheth, 
2004), Seema's first impression of America is that everything is big and almost everything is automated: Roads have four lanes, gas stations have eight pumps, stores are large and aisles are wide, washing machines and dishwashers replace washing clothes and dishes by hand, and vacuum cleaners supplant brooms. Some characters marvel at the bounty of food available. Brown (2004) writes in Little Cricket: "So much food for so little work, thought Kia in amazement. America really did have everything" (p.102). Vicenza notes, in Fresh off the Boat (DeLaCruz, 2005): "Supermarkets were a constant source of amazement for my family. A trip to the grocery story was like discovering a new continent.... 'This is a great and strange land,' my dad concluded, after surveying the overwhelming amount of choices in the cheese aisle: low-fat, nonfat, fat-free, reduced cholesterol, no carbohydrates, low sodium, or calcium added" (p. 36). While these may not be the most important aspects of the new culture, they are the ones that the characters first encounter and about which they respond strongly.

However, this wonderment quickly wears off as the characters compare the past with the present and reality sets in. In Behind the Mountains (Danticat, 2002), Celiane arrives in New York City from Haiti during a snowstorm. While she finds the snow beautiful, she quickly tires of it and finds the cold painful. Ramon, the best friend of protagonist Linda in Swimming to America (Mead, 2005), contrasts his life in the United States to that of his native Cuba. "Life here is hard for us.... We have a TV and milk to drink. We can buy things, which we couldn't do in Cuba. But it's not friendly around here" (p. 56).

Similarly, initial reactions to new foods range from fascination to disgust. The negative reactions are not solely on the basis of taste, but also tradition and mores. In Blue Jasmine (Sheth, 2004), Seema is nauseated by the smell of novel foods in the school cafeteria, and she and her vegetarian family are startled at the sight of a huge, headless bird at the center of the dining table at a Thanksgiving dinner they are invited to. In The King of Mulberry Street (Napoli, 2005), Dom, a hungry street urchin, refuses sandwiches with pork or meat and cheese together to uphold his Jewish kosher requirements (Napoli, 2005). Some protagonists do enjoy the food in their new country. Alem, in Refugee Boy (Zephaniah, 2001), is thrilled with the spaghetti in London, which he believes is more "authentic" than what he has had before.

For the protagonists, food is a key to belonging in their new lands. Young Ju, in A Step from Heaven ( $\mathrm{Na}, 2001$ ), learns to like doughnuts and hot cider to belong among her American friends. Seema, in Blue Jasmine (Sheth, 2004), switches from her Indian lunch of "roti bread, spicy peas, plain yoghurt, mango pickles... and sweet shiro, made of semolina roasted in butter and flavored with cardamom and saffron" (p. 50) to sandwiches. "Now, at lunch, I ate what everyone else was eating" (p. 51). In Fresh off the Boat (DeLaCruz, 2005), Vicenza ranks eating at Pizza Hut alongside owning a Clay Aiken album and Gap jeans as symbols of being "just as American as everyone else" (p. 103).

As with Vicenza's Gap jeans, clothing is another aspect of material culture that impacts the adjustment. Clothing serves as markers of social class, as when Dom of The King of Mulberry Street (Napoli, 2005) escapes detection as a 
stowaway because he is wearing shoes: it is inconceivable to the officials at Ellis Island that a poor boy would own shoes. Style and type of clothing also signify difference. In Ask Me No Questions (Budhos, 2006), Nadira goes to school wearing a Muslim headscarf and is teased. In Maya Running (Banerjee, 2005), Maya criticizes other Indian immigrants for wearing "high water" pants (i.e., pants that are too short) as well as her father who "like Halloween, wears his Canadian costume for Canadians, the Indian costume for Indians" (p. 6). In The Not-SoStar-Spangled Life of Sunita Sen (Perkins, 2005), Sunita wonders, "Was there a correct term for someone like Sunita Sen? On the outside, an Indian girl dressed in American clothes. On the inside, total confusion" (p.15).

The authors of these novels seem to suggest that the idea of who we are is integrally linked to the food we eat and the clothes we wear. While this may appear to be based on a narrow vision of what culture is, it is also true that these are indeed very important aspects of culture, particularly to teenagers. In addition, changes in food and attire are likely aspects that immigrant teenagers notice most immediately and that native teenagers may be most likely to notice about their immigrant counterparts. Therefore, examining literature that focuses on even this narrow conception of culture can be a window delving into deeper cultural differences. That the teenage protagonists undergo the "total confusion" of having to choose between the familiar and the new is related to issues of power and status, which we discuss next.

\section{Discussion}

Two interrelated themes emerged from our analysis of these three defining events in the process of immigration. The first theme, which we call "the dynamics of power," relates to the issue of actual and perceived socio-economic status differentials between immigrants and natives and between gender groups and generational status differentials among immigrants. The second theme, which we call "difference or deficit," examines the transformational impact of immigration. Across both themes is the sub-text of the author's voice. As mentioned earlier, issues of representation are key, as many authors explicitly stated that the purpose of writing their book was to "give voice" to their personal or their familial story of immigration. It is obviously not by chance that many demographic aspects of the protagonist mirror that of the author. Indeed, the novel becomes a literary device to examine the process of immigration and its accompanying issues of discrimination and assimilation through the various characters.

\section{The Dynamics of Power}

Writing of teacher education, Parameswaran (2007) notes that many education majors think of diversity as "a reflection merely of differences in 
customs, traditions, and values" (p. 53). She argues for the importance of also exploring "differences in power dynamics between the dominant and the subordinate groups in society" (p. 53). It is to those dynamics that we now turn.

In the stories, immigration brings about shifts of power in economic and social capital in both expected and unexpected ways. Upon immigrating, what constitutes valuable social capital shifts, and with it, power relationships shift as well. This is clearest in the descriptions about language throughout the books, both as a means of communication and as a form of self-identity, through one's name. As Portes and Rumbaut (2006) note, issues of immigration and language are about more than simply what language(s) immigrants speak. In the United States, rather than simple concern about whether or not immigrants can converse with non-immigrants, language takes on political implications: "The acquisition of nonaccented English and the dropping of foreign languages represent the litmus test of Americanization" (p. 207, emphasis ours). Thus, the dimension of power here is not just whether the immigrant who does not speak English (or who speaks "nonaccented" English) has less power than native-born Americans around him/her, but also whether nativist Americans worry about losing the power to dictate language use in their country.

We see these concerns played out in the stories in our sample. The characters from non-English-speaking countries all struggle with learning English, and even those who immigrate knowing English struggle with accents and idiomatic American-English. Even though some characters are bi- or multilingual, they are perceived by natives as being less intelligent due to their lack of fluent English, or their "foreign" accent. Sunita Sen is embarrassed when her friends laugh at her grandfather's Indian-accented, albeit impeccable English in The Not-So-Star-Spangled Life of Sunita Sen (Perkins, 2005). Negative reactions or assumptions based on English ability can be explained by Portes and Rumbaut's (2006) insight: these characters are being deemed as having failed this litmus test of Americanization.

Lack of access to English also limits what information is available to immigrants. For example, in Double Crossing the Balaban family speaks Yiddish, and thus can communicate only with the Jewish passengers on their boat (Tal, 2005). Most significantly, however, as the younger generation acquires Englishspeaking skills and, thus, the ability to participate more easily in the new culture, the status differential shifts from the older generation who lack this crucial social capital.

The impact of language on the power differential and self-identity is also seen through the issue of names. Gerhards and Hans (2009) argue in their study examining naming practices of immigrants in Germany that immigrants make important statements about acculturation and ethnic maintenance through the decisions they make about what to name their children. Gerhards and Hans (2009) focus on whether immigrant parents use German names when naming their newborns (acculturation) or names reflecting their culture of origin (ethnic maintenance). They also note several cases of forced acculturation, where governments required immigrant and/or ethnic groups to adopt only names 
reflecting the dominant culture. While there were not books in our sample that included new babies being named, we can extrapolate from Gerhards and Hans' (2009) research to see how power is implicated when it comes to immigrants' existing names as well. Several characters face frustration when Americans frequently mispronounce their names and are compelled to either shorten or Anglicize them. This was found especially in books with Asian protagonists. Correctly using an immigrant's original name can be seen as a validation of his/her home culture, whereas refusing to do so suggests that culture and, perhaps by extension that person, has little value.

The dynamics of power are also illustrated by acts of discrimination, both systemic and individual. Such discrimination against immigrants, or nativism, is often intertwined with racism, as often the most vociferous critiques of immigrants are heaped on those deemed to be racially inferior to the dominant group. Collins (2001) draws a comparison to the border policing that is central to immigration control and segregation, which maintains borders between racial groups. While there are similarities between racism and nativism, immigrants of color are subject to both types of discrimination, as seen in many of the novels we examined. Systemic discrimination is described in the historical novel The Bone Collector's Son (Yee, 2004), where Asians in Canada were restricted in terms of where they could live, where they could sit on streetcars, their education, and their medical treatment. Discrimination at an individual level manifests itself in the form of disrespect and ignorance from natives. In Refugee Boy (Zephaniah, 2001), Ethiopian-Eritrean Alem finds that there is a lot of hostility towards immigrants and refugees in England, particularly towards those of color. Kai finds that some people in the farmers' market do not want to buy food from her and other Hmong, in Little Cricket (Brown, 2004).

Struggles over power and respect also occur between immigrants and other ethnic minorities. In Finding My Hat (Son, 2003), there is conflict between Koreans and African Americans, and in The Not-So-Star-Spangled Life of Sunita Sen (Perkins, 2005), between Indians and African Americans. In addition, in Maya Running (Banerjee, 2005), Maya objects when classmates call her "nigger." The author seems to suggest that her objection is not because the word is offensive per se, but rather because she is Indian and does not like getting grouped together with Blacks.

Immigration can also cause a shift in gender relations within families. In The Braid (Frost, 2006), Double Crossing (Tal, 2005), and Ashes of Roses (Auch, 2002), all historical novels, the families experience stress as daughters find more freedom and a wider array of acceptable roles for themselves, which the parents, especially fathers, do not always welcome. Conversely, the repercussions for girls of families not wishing to adopt the new customs is presented in No Laughter Here (Williams-Garcia, 2004), in which Victoria undergoes female circumcision when she returns to Nigeria for her summer vacation. 


\section{Difference or Deficit?}

Closely related to the theme of power is the theme of difference. A central feature of adolescent life is the desire to "fit in," and this is what immigrants at time strive for and at times have been forced to do. Therefore, it makes sense that difference would loom large in books related to those who are both immigrants and adolescents. In the United States, there has often been pressure on immigrants to Americanize, or what Portes and Rumbaut (2006) call forced assimilation. In such a paradigm, immigrant difference is clearly defined as deficit. Those who advocate such efforts see immigrant inability, or refusal, to assimilate completely as a threat to national unity (Portes \& Rumbaut, p. 348).

Perhaps because the books are about young adulthood, a stage of life when issues of personal identity and coming of age predominate, the question of cultural identity is a major aspect of this theme. The young people portrayed are delicately balanced between two worlds. However, in the minds of many of the protagonists, as well as many of their American peers, difference equals deficit, with the implicit assumption that the ways of the home country are not desirable, and so the young immigrants strive to assimilate as much as possible. For example, in Swimming to America (Mead, 2005), Linda's Albanian mother criticizes her for calling her "Ma," when she should call her "Nane." Linda replies, "You know I can't call you that - it's un-American" (p. 10). Yara, in Flight to Freedom (Veciana-Suarez, 2002), expresses much frustration with this feeling of always being different:

At home I knew all the girls in class, and my teachers knew me. Here, I am nobody. Worse, in school I'm convinced I appear odd and out of place, like being the lone mango tree in a field of mameys.... I could feel my new classmates staring at me as if I were a visitor from outer space. Well, maybe I am, because that's how I feel (p. 48).

In a few cases, protagonists strongly resist such assimilation, prefer how things are done in their home country, and hold closely to their traditions. In several books, the authors introduce a secondary character, often a sibling, who undergoes unconditional assimilation, to highlight some of the associated problems. For instance, in A Step from Heaven (Na, 2001) and Little Cricket (Brown, 2004), the protagonists' brothers reject the ways of the home country entirely and end up getting in trouble. By the same token, some books include a character who maintains an uncompromising stance of non-assimilation, such as the grandfather in Little Cricket (Brown, 2004), who also, in time, sees the error of his ways.

Essentially, all the novels follow the story arc of a) rejecting American culture; b) embracing American culture and rejecting the home culture; and c) realizing that the best alternative is to accept elements of both cultures, while recognizing that taking on some American culture does not necessarily mean losing all of one's native culture. Thus, the authors seem to conclude that the 
best position is a hybrid - embracing elements of both American and the home culture. While again, these are fictional accounts, this mirrors the sociological concept of selective acculturation, defined by Portes and Rumbaut (2006) as being when children "acculturate to American ways without abandoning their parents' language and key elements of their culture" (p. 267). These authors argue that generally, this approach leads to the greatest success among immigrant youth, and those immigrant youth reading these novels would come away with the message, whether intended or not, that such selective acculturation is both possible and encouraged.

Given that American immigration history and practice has been based on the principle of the "melting pot," or assimilation, where all immigrants are pressured to become "Americanized," behaving and talking in acceptable and recognizable ways, the emphasis in these books on the creation of a hybrid immigrant who incorporates the best of both home and adopted cultures, or selectively acculturates, is encouraging.

We can attribute this at least in part to representation of voice: eight out of the 20 authors are immigrants themselves, and those who were all wrote about experiences of immigrants from their own countries. Indeed, in Behind the Mountains, author Edwidge Danticat (2002) includes her own experience of emigrating from Haiti in an epilogue, noting the many parallels between her life and Celiane's. Their personal journeys of immigration have informed and lent richness to these stories, helping us to appreciate and understand better the challenges facing immigrants and the hybridization of the today's American immigrant.

\section{Conclusion}

Immigration is not a one-time event that begins and ends with an official stamp of approval at a port of entry into a new country, but a process that continues indefinitely, in some cases, even through the rest of one's life, punctuated by defining events along the way. Would-be immigrant families or individuals undergo a series of prior experiences that result in the decision to relocate. Factors that impel the decision may be economic, to improve their living standard, or political, to escape persecution or discrimination in the home country. The journey of immigration is another significant event, and in the case of escaping families, a traumatic, frightening, and stressful experience, sometimes resulting in the deaths of family members. Yet, all these changes and adjustments pale somewhat in the context of the most difficult adjustment the families have to make upon immigration, the third pivotal juncture of this process, as they assimilate into their new environment and "become American." As the realities of life in America set in, and in particular the harshness of immigrant life, the new immigrants realize they must give up their old ways of life and adapt to their new home. 
With more young adult fiction exploring these themes, the hope is that immigrant students will relate better to books that reflect something akin to what they have been through and that native students will better understand their immigrant peers through such reading. As Loh (2009) argues, "The use of a variety of cross-cultural literary texts can serve to portray a pluralistic and changing American world" (p. 291). Teachers would do well to expose immigrant and native-born students alike to such fiction, as a springboard to a richer understanding of their own lives and the world around them.

\section{Notes}

1. This includes immigrants, refugees, and asylees. While there are important distinctions among these types, in this paper we use the term "immigrants" as an inclusive term, encompassing all three of these groups.

2. The act of immigrating - moving to a new country - is also an act of emigrating - leaving the old country. Thus, it can be tricky to decide which term to use. When the reference point is the old country, we used "emigration." When the reference point is the new country, we used "immigration." In a few instances, however, both processes seemed equally relevant, in which case we defaulted to using the term "immigration."

3. The rubric and a more detailed discussion of methodology are available upon request from first author.

4. One of the books, Helen Frost's The Braid, had two protagonists, both female.

5. "Meo" was a derogatory name used for the Hmong.

6. Luckily, her fears are unfounded, as their reunion, when she immigrates, is warm; their relationship resumes relatively easily (and he has no new family).

\section{References}

Auch, M. (2002). Ashes of roses. New York: Dell Laurel Leaf Press.

Banerjee, A. (2005). Maya running. New York: Laurel Leaf Press.

Barle, L. R. (2008). The database of award-winning children's literature, Retrieved from http://www.dawcl.com

Brown, J. (2004). Little cricket. New York: Hyperion Books for Children.

Budhos, M. (2006). Ask me no questions. New York: Simon Pulse.

Danticat, E. (2002). Behind the mountains. New York: Orchard Books.

De La Cruz, M. (2005). Fresh off the boat. New York: Harper Collins. 
Erikson, E. H. (1980). Identity and the life cycle. New York: W.W. Norton.

Fortuny, K. (2010, September). Children of Immigrants: 2008 State Trends Update. The Urban Institute, Brief 17.

Frost, H. (2006). The braid. New York: Farrar, Strauss, and Giroux.

Gerhards, J., \& Hans, S. (2009). From Hasan to Herbert: Name-giving patterns of immigrant parents between acculturation and ethnic maintenance. American Journal of Sociology, 114(4), 1102-1128.

Hinton, K. (2006). "Trial and error: A framework for teaching multicultural literature to aspiring teachers." Multicultural Education, 13(4), 51-54.

Hobbs, W. (2006). Crossing the wire. New York: Harper Collins.

Keis, R. (2006). From principle to practice: Using children's literature to promote dialogue and facilitate the 'coming to voice' in a rural Latino community. Multicultural Perspectives, 8(1), 13-19.

Lamme, L., Fu, D., \& McKoy Lowery, R. (2004). Immigrants as portrayed in children's picture books. Social Studies, 95(3), 123-129.

Lasky, K. (2005). Broken song. Puffin Books.

Loh, C. (2009). "Reading the world: Reconceptualizing reading multicultural literature in the English language arts classroom in a global world," Changing English, 16(3), 287-299.

Mead, A. (2005). Swimming to America. New York: Farrar, Straus, and Giroux.

Mullen, B. (2004). Sticks and stones can break my bones, but ethnophaulisms can alter the portrayal of immigrants to children. Personality and Social Psychology Bulletin, 30, 250-260.

$\mathrm{Na}$, A. (2001). A step from heaven. New York: Penguin Putnam Books for Young Readers.

Napoli, D. (2005). The king of Mulberry Street. New York: Random House.

Parameswaran, G. (2007). "Enhancing Diversity Education," Multicultural Education, 14(3), 51-55.

Perkins, M. (2005). The not-so-star-spangled life of Sunita Sen. New York: Little, Brown Books for Young Readers.

Portes, A., \& Rumbaut, R. (2006). Immigrant America: A portrait ( $3^{\text {rd }}$ edition). Berkeley: University of California Press.

Sheth, K. (2004). Blue jasmine. New York: Hyperion Books for Children.

Son, J. (2003). Finding my hat. New York: Orchard Books.

Senate Bill 1070. Retrieved from http://www.azleg.gov

Tal, E. (2005). Double crossing. El Paso, TX: Cinco Puentos Press.

Veciana-Suarez, A. (2002). Flight to freedom. New York: Orchard Books. 
Williams-Garcia, R. (2004). No laughter here. New York: Harper Collins.

Yee, P. (2004). The bone collector's son. Tarrytown, NY: Marshall Cavendish.

Zephaniah, B. (2001). Refugee boy. New York: Bloomsbury USA Children's Books.

\section{Appendix:}

\section{Demographic Information on Protagonists and Authors of Immigrant Narratives in Sample}

\begin{tabular}{|c|c|c|c|c|c|c|c|c|}
\hline \multirow[b]{2}{*}{$\begin{array}{c}\text { Details of } \\
\text { book }\end{array}$} & \multirow[b]{2}{*}{$\begin{array}{l}\text { Period } \\
\text { set in }\end{array}$} & \multicolumn{6}{|c|}{ Details on Protagonist } & \multirow[b]{2}{*}{$\begin{array}{l}\text { Auth- } \\
\text { or } \\
\text { immig } \\
\text { rant? }\end{array}$} \\
\hline & & Name & Sex & $\begin{array}{l}\text { Nation } \\
\text { ality of } \\
\text { Origin }\end{array}$ & $\begin{array}{l}\text { Ethni- } \\
\text { city }\end{array}$ & $\begin{array}{l}\text { Reli- } \\
\text { gion }\end{array}$ & $\begin{array}{c}\text { Resi- } \\
\text { dence } \\
\text { of } \\
\text { Immi- } \\
\text { gration }\end{array}$ & \\
\hline $\begin{array}{c}\text { Auch, Mary } \\
\text { Jane. } 2002 . \\
\text { Ashes of Roses }\end{array}$ & Hist & $\begin{array}{l}\text { Rose } \\
\text { Nolan }\end{array}$ & $\mathrm{F}$ & Ireland & Irish & $\begin{array}{l}\text { Catho- } \\
\text { lic }\end{array}$ & $\begin{array}{l}\text { New } \\
\text { York } \\
\text { City }\end{array}$ & No \\
\hline $\begin{array}{c}\text { Banerjee, } \\
\text { Anjali. } 2005 . \\
\text { Maya Running }\end{array}$ & $\begin{array}{l}\text { Con- } \\
\text { temp }\end{array}$ & $\begin{array}{l}\text { Mayasri } \\
\text { Mukher- } \\
\text { jee }\end{array}$ & $\mathrm{F}$ & India & Bengali & Hindu & $\begin{array}{l}\text { Mani- } \\
\text { toba, } \\
\text { Canada }\end{array}$ & $\begin{array}{l}\text { Yes } \\
\text { (India) }\end{array}$ \\
\hline $\begin{array}{c}\text { Brown, Jackie. } \\
\text { 2004. Little } \\
\text { Cricket }\end{array}$ & $\begin{array}{l}\text { Con- } \\
\text { temp }\end{array}$ & $\begin{array}{c}\text { Kia } \\
\text { Vang }\end{array}$ & $\mathrm{F}$ & $\begin{array}{l}\text { Laos } \\
\text { PDR }\end{array}$ & Hmong & Animist & $\begin{array}{l}\text { Minnea- } \\
\text { polis }\end{array}$ & No \\
\hline $\begin{array}{c}\text { Budhos, } \\
\text { Marina. } 2006 . \\
\text { Ask Me No } \\
\text { Questions }\end{array}$ & $\begin{array}{l}\text { Con- } \\
\text { temp }\end{array}$ & Nadira & $\mathrm{F}$ & $\begin{array}{c}\text { Bangla } \\
\text { desh }\end{array}$ & Bengali & Muslim & $\begin{array}{c}\text { Flushing } \\
\text { NY }\end{array}$ & No \\
\hline $\begin{array}{c}\text { Danticat, } \\
\text { Edwidge. } 2002 . \\
\text { Behind the } \\
\text { Mountains }\end{array}$ & $\begin{array}{l}\text { Con- } \\
\text { temp }\end{array}$ & $\begin{array}{l}\text { Celiane } \\
\text { Espe- } \\
\text { rance }\end{array}$ & $\mathrm{F}$ & Haiti & Haiti & Haitian & NA & $\begin{array}{l}\text { Yes } \\
\text { (Haiti) }\end{array}$ \\
\hline $\begin{array}{c}\text { De La Cruz, } \\
\text { Melissa. } 2005 . \\
\text { Fresh off the } \\
\text { Boat }\end{array}$ & $\begin{array}{l}\text { Con- } \\
\text { temp }\end{array}$ & $\begin{array}{l}\text { Vicenza } \\
\text { Aram- } \\
\text { bulo }\end{array}$ & $\mathrm{F}$ & $\begin{array}{l}\text { Philippi } \\
\text { nes }\end{array}$ & Filipina & $\begin{array}{c}\text { Catho- } \\
\text { lic }\end{array}$ & $\begin{array}{l}\text { San } \\
\text { Fran- } \\
\text { cisco }\end{array}$ & $\begin{array}{l}\text { Yes } \\
\text { (Philip } \\
\text { pines) }\end{array}$ \\
\hline $\begin{array}{c}\text { Frost, Helen. } \\
\text { 2006. The } \\
\text { Braid }\end{array}$ & Hist & $\begin{array}{c}\text { Jeannie } \\
\text { \& Sarah } \\
\text { Mac- } \\
\text { Kinnon }\end{array}$ & $\mathrm{F}$ & $\begin{array}{c}\text { Scotlan } \\
d\end{array}$ & $\begin{array}{l}\text { Scot- } \\
\text { tish }\end{array}$ & $\begin{array}{c}\text { Chris- } \\
\text { tian }\end{array}$ & $\begin{array}{l}\text { Nova } \\
\text { Scotia, } \\
\text { Canada }\end{array}$ & No \\
\hline
\end{tabular}




\begin{tabular}{|c|c|c|c|c|c|c|c|c|}
\hline $\begin{array}{l}\text { Hobbs, Will. } \\
\text { 2006. Crossing } \\
\text { the Wire }\end{array}$ & $\begin{array}{l}\text { Con- } \\
\text { temp }\end{array}$ & Victor & $M$ & Mexico & $\begin{array}{l}\text { Mexi- } \\
\text { can }\end{array}$ & & $\begin{array}{l}\text { North- } \\
\text { west } \\
\text { U.S. }\end{array}$ & No \\
\hline $\begin{array}{l}\text { Lasky, Kathryn. } \\
\text { 2005. Broken } \\
\text { Song }\end{array}$ & Hist & $\begin{array}{c}\text { Reuven } \\
\text { Bloom }\end{array}$ & $\mathrm{M}$ & Russia & $\begin{array}{l}\text { Rus- } \\
\text { sian } \\
\text { Jew }\end{array}$ & Jewish & $\begin{array}{l}\text { New } \\
\text { York } \\
\text { City }\end{array}$ & No \\
\hline $\begin{array}{l}\text { Mead, Alice. } \\
2005 . \\
\text { Swimming to } \\
\text { America }\end{array}$ & $\begin{array}{l}\text { Con- } \\
\text { temp }\end{array}$ & $\begin{array}{l}\text { Linda } \\
\text { Berati }\end{array}$ & $\mathrm{F}$ & Albania & $\begin{array}{l}\text { Alba- } \\
\text { nian }\end{array}$ & & $\begin{array}{l}\text { New } \\
\text { York } \\
\text { City }\end{array}$ & No \\
\hline $\begin{array}{c}\mathrm{Na}, \text { An. } 2001 . \\
\text { A Step From } \\
\text { Heaven }\end{array}$ & $\begin{array}{l}\text { Con- } \\
\text { temp }\end{array}$ & $\begin{array}{c}\text { Young } \\
\text { Ju }\end{array}$ & $\mathrm{F}$ & Korea & Korean & $\begin{array}{c}\text { Chris- } \\
\text { tian }\end{array}$ & $\begin{array}{l}\text { South- } \\
\text { ern Cali- } \\
\text { fornia }\end{array}$ & $\begin{array}{l}\text { Yes } \\
\text { (Ko- } \\
\text { rea) }\end{array}$ \\
\hline $\begin{array}{l}\text { Napoli, Donna } \\
\text { Jo. 2005. The } \\
\text { King of } \\
\text { Mulberry Street }\end{array}$ & Hist & $\begin{array}{l}\text { Benai- } \\
\text { mino } \\
\text { (Dom) }\end{array}$ & $\mathrm{M}$ & Italy & $\begin{array}{l}\text { Italian } \\
\text { Jew }\end{array}$ & Jewish & $\begin{array}{l}\text { New } \\
\text { York } \\
\text { City }\end{array}$ & No \\
\hline $\begin{array}{l}\text { Perkins, Mitali. } \\
\text { 2005. The Not- } \\
\text { So-Star- } \\
\text { Spangled Life } \\
\text { of Sunita Sen }\end{array}$ & $\begin{array}{l}\text { Con- } \\
\text { temp }\end{array}$ & $\begin{array}{c}\text { Sunita } \\
\text { Sen }\end{array}$ & $\mathrm{F}$ & Indian & Bengali & $\begin{array}{l}\text { Hindu } \\
\text { implied }\end{array}$ & $\begin{array}{l}\text { San } \\
\text { Fran- } \\
\text { cisco }\end{array}$ & $\begin{array}{l}\text { Yes } \\
\text { (India) }\end{array}$ \\
\hline $\begin{array}{l}\text { Sheth, } \\
\text { Kashmira. } \\
\text { 2004. Blue } \\
\text { Jasmine }\end{array}$ & $\begin{array}{l}\text { Con- } \\
\text { temp }\end{array}$ & $\begin{array}{l}\text { Seema } \\
\text { Trivedi }\end{array}$ & $\mathrm{F}$ & Indian & $\begin{array}{l}\text { Guja- } \\
\text { rati }\end{array}$ & Hindu & $\begin{array}{l}\text { lowa } \\
\text { City }\end{array}$ & $\begin{array}{l}\text { Yes } \\
\text { (India) }\end{array}$ \\
\hline $\begin{array}{l}\text { Son, John. } \\
\text { 2003. Finding } \\
\text { My Hat }\end{array}$ & $\begin{array}{l}\text { Con- } \\
\text { temp }\end{array}$ & $\begin{array}{c}\text { Jin-Han } \\
\text { Park }\end{array}$ & M & Korea & Korean & $\begin{array}{c}\text { Chris- } \\
\text { tian }\end{array}$ & $\begin{array}{l}\text { Chicago } \\
\text { Mem- } \\
\text { phis, } \\
\text { Houston }\end{array}$ & $\begin{array}{l}\text { Yes } \\
\text { (Ko- } \\
\text { rea) }\end{array}$ \\
\hline $\begin{array}{c}\text { Tal, Eve. } 2005 . \\
\text { Double } \\
\text { Crossing }\end{array}$ & Hist & $\begin{array}{c}\text { Raizel } \\
\text { Balaban }\end{array}$ & $\mathrm{F}$ & $\begin{array}{l}\text { Ukrain } \\
\text { e/ } \\
\text { Russia }\end{array}$ & $\begin{array}{l}\text { Rus- } \\
\text { sian } \\
\text { Jew }\end{array}$ & Jewish & $\begin{array}{l}\text { New } \\
\text { York } \\
\text { City }\end{array}$ & No \\
\hline $\begin{array}{l}\text { Veciana- } \\
\text { Suarez, Ana. } \\
\text { 2002. Flight to } \\
\text { Freedom }\end{array}$ & $\begin{array}{l}\text { Con- } \\
\text { temp }\end{array}$ & Yara & $\mathrm{F}$ & Cuba & Cuban & $\begin{array}{l}\text { Catho- } \\
\text { lic }\end{array}$ & Miami & $\begin{array}{l}\text { Yes } \\
(\mathrm{Cu}- \\
\mathrm{ba})\end{array}$ \\
\hline $\begin{array}{l}\text { Williams- } \\
\text { Garcia, Rita. } \\
\text { 2004. No } \\
\text { Laughter Here }\end{array}$ & $\begin{array}{l}\text { Con- } \\
\text { temp }\end{array}$ & Victoria & $\mathrm{F}$ & Nigeria & Yoruba & NA & $\begin{array}{c}\text { Queens, } \\
\text { NY }\end{array}$ & No \\
\hline
\end{tabular}




\begin{tabular}{|c|c|c|c|c|c|c|c|c|}
\hline $\begin{array}{c}\text { Yee, Paul. } \\
\text { 2004. The } \\
\text { Bone } \\
\text { Collector's Son }\end{array}$ & Hist & Bing & $\mathrm{M}$ & China & $\begin{array}{c}\text { Chi- } \\
\text { nese }\end{array}$ & $\begin{array}{c}\text { Bud- } \\
\text { dhist }\end{array}$ & $\begin{array}{c}\text { Van- } \\
\text { couver, } \\
\text { Canada }\end{array}$ & No \\
\hline $\begin{array}{c}\text { Zephaniah, } \\
\text { Benjamin. } \\
\text { 2001. Refugee } \\
\text { Boy }\end{array}$ & $\begin{array}{c}\text { Con- } \\
\text { temp }\end{array}$ & Alem & $\mathrm{M}$ & $\begin{array}{c}\text { Ethio- } \\
\text { pia/ } \\
\text { Eritrea }\end{array}$ & $\begin{array}{c}\text { Ethio- } \\
\text { pian/Eri } \\
\text { trean }\end{array}$ & NA & $\begin{array}{c}\text { London, } \\
\text { Eng- } \\
\text { land }\end{array}$ & No \\
\hline
\end{tabular}

